\title{
T.R.E
}

\section{Educational justice and the gifted}

\author{
M I C H A E L S. M E R R Y \\ Beloit College, Wisconsin, USA
}

\begin{abstract}
A B S T R A C T
This article examines two basic questions: first, what constitutes a gifted person, and secondly, is there justification in making special educational provision for gifted children, where special provision involves spending more on their education than on the education of 'normal' children? I consider a hypothetical case for allocating extra resources for the gifted, and argue that gifted children are generally denied educational justice if they fail to receive an education that adequately challenges them. I further argue that an adequately challenging education is essential to human flourishing, but that most children can be adequately challenged in schools in ways that promote flourishing without doing so at the expense of other children.
\end{abstract}

K E Y W O R D S adequate challenge, fair equality of opportunity, flourishing, giftedness

With the Passage of the Elementary and Secondary Education Act (ESEA) in 1965 , the needs of various minority children in the United States became the subject of federal policy. Title I legislation aimed to close the achievement gap between high and low achieving children, 'especially the achievement gaps between the minority and non-minority students, and between disadvantaged children and their more advantaged peers' (ESEA, Sec. IOoI.3). Some years later, the Rehabilitation Act (1973) and the Education for All Handicapped Children Act (PL 94-I42, I975) were passed to provide educational opportunities for children with disabilities and special needs. This legislation effectively required the inclusion - to one degree or another into regular classroom instruction - of children with special needs whose parents wished to avail themselves of the public schools. Assessment and accountability procedures were also prescribed. ${ }^{I}$ Eventually this legislation would be ratified as the Individuals with Disabilities Education Act (IDEA). As an entitlement program, schools receiving federal funds under IDEA are responsible for actively seeking out children who may benefit from the services that said legislation addresses.

\section{Theory and Research in Education}

Copyright (C) 2008, SAGE PUblications, www.sagepublications.com VOL 6(I) 47-70 ISSN I477-8785 DOI: IO.II77/I 477878507086730 
The relevance of these developments is to highlight an important backdrop to the demand for equitable education for children whose parents consider them to be 'gifted'. In the last 30 years or so, a growing number of mostly white, middle-class parents have expressed outrage at the failure of public schools to adequately challenge their children. Gifted children, the argument runs, are underserved, are being 'held back', and are being asked to pull others up without being challenged themselves. Anecdote after anecdote is served up suggesting that gifted children suffer ennui, frustration and often disaffection with their schooling as a result of not being sufficiently challenged. Some parents also complain that they are forced to pay for private education or tutoring in order to challenge their children with exceptional abilities or talents. Many of these parents have demanded that states and/or the federal government appropriate funds for separate gifted and talented programming as a matter of equity and equal opportunity. However, despite vociferous demands for special accommodation and programming, special provisions for so-called gifted children have largely fallen on deaf ears. ${ }^{2}$ Individual states may address the matter separately, ${ }^{3}$ and in certain instances court decisions have required that some programs for gifted children be provided.Vexed that more than I4O per cent extra is spent on special education services than on 'enrichment' services for quick learners, a small but committed core of parents continue to push for special legislation and funding for Talented and Gifted programming (Cloud, 2007; Davidson and Davidson, 2004). ${ }^{4}$

Vocal critics argue that giftedness labeling and programming in public schools is elitist and operates according to doubtful psychometric assessment tools which generally privilege a select few at the expense of the majority. Making the debate possibly more contentious is the belief many have that the number of truly exceptional children who are likely to require extraordinary educational provision is rather small - unlike the population of children deemed to have 'special needs'. 5 Yet I argue that, while only a small number of truly exceptional children are likely to require extraordinary educational provision, to not adequately challenge these children, who hail from all ethnic groups and social classes, is unequivocally to fail them.

This article addresses two important questions.

I. What constitutes a gifted person?

2. Are we justified in making special educational provision for gifted children, where special provision involves spending more on their education than on the education of 'normal' children?

Taking the first item, I will attempt to define the notion of giftedness, noting its inherent complexity and contested nature. I will briefly consider a multifactorial concept of intelligence and suggest that notwithstanding its advantages 


\title{
Merry: Educational justice and the gifted
}

it cannot supply a theoretical foundation for gifted education and may actually serve to undermine it. This is because intelligence or ability too broadly defined renders gifted education either trivial or useless. Though advocates of 'multiple intelligence' will locate giftedness in various domains (e.g. intuitive, intrapersonal, affective), I will concern myself with its cognitive aspects in this article. As a corollary to the first question, I will then examine the difficulties in determining who is gifted, noting cultural, environmental and institutional barriers.

Then, taking the second question, I will consider a hypothetical case for allocating extra resources for the gifted, considering various political and educational arguments. I will turn my attention to Rawls' second axiom of justice, focusing in particular on Fair Equality of Opportunity (FEO), which requires not only 'that public offices and social positions be open in the formal sense, but that all should have a fair chance to attain them' (Rawls, 200I: 43). That is, persons with similar native endowments (talent and ability), and the initiative or motivation to put those talents to effective use, ought to have more or less the same opportunities to do so irrespective of their family and social class origins. Notwithstanding its philosophical appeal, I will show that FEO can not justify differential educational provision for those who have more talent than others.

Leaving Rawls aside, then, I will introduce a principle of adequate educational challenge. Thus, in response to my second question, my central claim is this:

\author{
All children, including the gifted, deserve to be \\ adequately challenged as a matter of fairness, even \\ though the specification of what is adequate will continue \\ to be somewhat elusive.
}

I argue that gifted children are generally denied educational justice if they fail to receive an education that adequately challenges them. I also argue that an adequately challenging education is essential to human flourishing.

I will further argue that most children can be adequately challenged in schools in ways that promote flourishing without doing so at the expense of other children. Justice demands that classroom instruction - and educational opportunities generally - should not be arranged in such a way as to unduly advantage children whose abilities arguably surpass those of their classmates. Rather, educational opportunities must be structured so as to benefit all learners irrespective of socio-economic background, parental and teacher recommendation, or test scores.

\section{WHAT CONSTITUTES A GIFTED PERSON?}

Giftedness is one of those terms that would seem to defy precise description. Yet how we conceive of giftedness is hugely significant because this will inform not only our understanding of who gifted learners are, but moreover 
how we ought to design and foster educational opportunities. Experts use a number of criteria when discussing gifted individuals. These criteria include a tendency to ask probing questions, signs of astute analysis, or the ability to synthesize complex information (Heller et al., 2005). Others speak of being goaldriven, possessing greater metacognition, a faster pace of learning, greater flexibility in problem-solving skills, and a penchant for complexity and challenge (Callahan and Miller, 2005). Other factors are also germane, such as intrinsic motivation and sustained attention or task commitment, but it remains unclear just how other these are to be factored in. Matters become increasingly complex when we include learning styles, creativity, memory capacity, strategies for coping with stress, and good old-fashioned practice and hard work. What is clear is that a lot of information is needed to properly evaluate what a child's abilities or gifts are and how they might best be cultivated. Yet given the fact that 'giftedness may be elusive in its manner and context of manifestation' (VanTassel-Baska, 2005a: 364), some have suggested that we broaden the possibilities for identifying unusually talented individuals. One way to do that is to consider a multifactorial concept of intelligence.

A multifactorial concept of intelligence takes a more expansive view of things, effectively abrogating the popular notion that only a few individuals possess unique talents or unusually high ability. On such an understanding, all but the most incapacitated and irresolute possess (and possibly excel at) one or more types of intelligence and are capable of cultivating other intelligences over time that have been undernourished or in which, for the time being, they are lacking in proficiency. Thus individuals with developed spatial or interpersonal intelligences are not as likely to demonstrate mathematical or analytical aptitude. Yet where competency may be lacking in one form of intelligence, its advocates answer that this can be corrected by providing adequate learning opportunities and an appropriate level of challenge. According to Howard Gardner:

[T] he 'smarter' the environment and the more powerful the interventions and the available resources, the more proficient people will become, and the less important will be their particular genetic inheritance. (Gardner, I999: 88)

On this understanding 'giftedness' appears not to be a state of being for most children; it is something more akin to a process. Thus, given the right set of conditions and opportunities, many more children than at present would certainly be considered 'gifted'; indeed, most children might be 'gifted' in at least one area. In fact this is the direction in which such theories can be extrapolated.Yet the problem with appropriating a multifactorial formulation of intelligence is that by expanding the definition of giftedness or ability to encompass all but the most incorrigibly untalented and mentally challenged, the notion of 'giftedness' becomes rather devoid of content. ${ }^{6}$ Indeed, for giftedness to apply in some broad sense to all children except the most severely disabled is to dilute 
the significance of giftedness that its advocates insist make it remarkable in the first place. Further, while it is desirable that schools expand the notion of giftedness to include those whose abilities and talents fall outside the time-honored categories of math, science and language arts, it does not follow that the gifted in these or any other subject or activity are deserving of special or separate instruction. Rather, it throws down a challenge to provide good teaching and effective instruction to all children irrespective of how well they perform on evaluative instruments whose purpose is to assess abilities according to a set of criteria on which there is little agreement.

So the problem of achieving consensus on the precise meaning of giftedness continues to dog the field, and the difficulties are compounded by those who interchange terms like 'genius' or 'prodigy' with 'gifted' (Davidson and Davidson, 2004). In light of these difficulties, some argue that we ought to do away with the gifted label altogether:

[Defining] giftedness is a matter of values and policy, not empirical research. And in many, if not most, states, definitions are not mandated. The result is that local educators are free, indeed required, to choose, or write, a definition of giftedness for their program for gifted students, one that, to a large extent, determines who will and who will not be gifted. In other words, giftedness in the schools is something we confer, not something we discover. It is a matter of educational policy, not a matter of scientific diagnosis. It is a social construction, not a fact of nature. (Borland, 2005: 8)

Others, however, continue to employ definitions - albeit with great caution even as they admit that the entire enterprise is 'nebulous and fraught with difficulty.

The highly able child is someone who has significantly greater aptitude for some aspect of intellectual learning than would be considered typical for their age and background.

(Winstanley, 2003: 35)

Now, clearly this broad definition does little to allay the vagueness problem, and, given the difficulties in arriving at a definition on which all can agree, I shall simply note here the contentiousness of the terminology in question. Yet, while the difficulty in defining the gifted child can be messy business, practical demands require that we use some definition to refer to those children whose unusual aptitude sets them apart from their peers.

Throughout I will use 'gifted' to refer to children with unusual abilities. 'Unusual abilities' on its own is terribly imprecise, of course, and unhelpful without further qualification. For example, a great many individuals possess some unusual talent or ability that few others do. Most of these 'talents' are physical eccentricities - often showcased on late-night television - and are generally quite useless aside from their (limited) amusement value. So possessing unusual abilities may mean little more than having atypical characteristics or abilities, and there is nothing noteworthy in the gifted sense about this. 
Further, not all gifted children are recognized as such, and this may prevent them from being correctly identified in the first place. Indeed, some may demonstrate decidedly anti-social behavior and unremarkable test results. In other cases, however, children possess abilities simply not valued in the culture or society they inhabit. Either way, only appropriately varied diagnostics and monitoring can determine whether a child is simply 'quirky' or exceptional. Though some will doubtless prefer that we appreciate the various ways in which giftedness manifests itself (e.g. intuitively, affectively), by unusual abilities I have in mind those who possess extraordinary cognitive capacities well beyond what is considered 'average' for one's age or background. Thus, like Winstanley, I will limit my use of giftedness here to its cognitive sense.

\section{WHO ARE THE GIFTED?}

The common understanding of giftedness among its advocates assumes that gifted children have, innately, some learning capacity (parsed out in a variety of forms) that other children do not. Yet, aside from the conceptual difficulties, there are also a number of empirical realities that create difficulties for identifying gifted persons. First, some cultures will discourage any form of recognition of individual talent, preferring instead to emphasize communal values and group efforts. Second, children with unusual abilities often have their talents and intelligence obscured by several factors. There may be learning disabilities of various kinds (e.g. dyslexia) or sensory impairment (e.g. hearing loss). Some gifted children may also suffer from various chemical imbalances (e.g. hyperactive thyroid) or dwell in unstable home environments, thus affecting their academic performance. Further, a child's elder siblings may not have been model students, thus leading many teachers to expect less of them. Other criticisms point to the fact that tests used to measure intelligence are able to tell us little about how the mind works or what a child's aptitude or learning potential actually is. Individuals who score well on tests may be highly intelligent or they may simply be proficient at taking tests.

Finally, because of the ways that tracking and ability grouping in public schools actually work, 'gifted' labeling frequently maps along both racial and social class lines. Whites and Asians are twice as likely as Latinos or African Americans to be labeled 'gifted' even with comparable test scores (Borland and Wright, 1994; Ford and Harris, 1999; Gordon and Birdglall, 2005; Moore et al., 2005). There may be a variety of reasons for this, including the learning opportunities that some parents provide their children at home or outside of the home/school. Be that as it may, parents and teachers routinely make certain assumptions about children particularly of a certain social class background - and their putative abilities. What is more, these assumptions quickly become labels, and these labels usually stick. 


\section{Merry: Educational justice and the gifted}

Laura Purdy writes that not only are there problems with identifying appropriate participants in special programs, there is the problem of 'snobbery among the chosen, together with the lack of self-confidence among those not chosen [and] such labels may be artificial and self-fulfilling prophecies based on inadequate criteria' (2007: 318). In light of this worrying trend, there are good reasons to question whether most children who are designated 'gifted learners' in schools are truly deserving of the label. (Similarly, our skepticism is justified as it concerns the assignment of 'learning disabilities' to children from various minority groups (Harry and Klingner , 2006; Losen and Orfield, 2002).)

The manner in which social class bears upon gifted labeling is particularly telling. Consider the social conditions that facilitate the cultivation of talents and the level of interest and effort that are likely to accrue given (a) the right learning conditions to foster those talents including appropriate role models and expectations; and (b) a set of opportunities and incentives that value and reward certain talents. Take, for example, a child whose latent proficiency lies in composing music, yet she has non-musical parents and attends a school that has no budget for a music program. Were she to have musically talented parents or were this music program to exist, she might have the conditions under which her untapped talents might flourish. Moreover, if she is lucky enough to have her hidden talents recognized and valued by her parents and teachers, she would have at her disposal a strong incentive to continue developing her talents in ways that open doors of opportunity not available to her in the absence of such parents or programs. The issue here is certainly whether or not a child's talents and/or gifts are recognized and valued, but also whether the opportunities and conditions exist for those uncultivated talents and gifts to emerge and to blossom in the first place.

Of course opportunities and incentives are no guarantee of interest, intention or effort; nor are opportunities a substitute for actual aptitude or talent. And while cultivating talent entails more than merely finding out what one is good at, opportunities continue to correspond closely to social class and the sorts of preferences and tastes social class affords. Thus a privileged child lacking in the dexterity or motivation required for, say, gymnastics may adapt her preferences, provided she has both the requisite guidance and resources, and pursue other, culturally valued, pursuits. Even in the absence of motivation or talent, a socially privileged child may turn her attention to other activities which may or may not satisfy culturally established criteria for valued pursuits. Moreover, given the range of choices available to a socially privileged child, the likelihood that she will experience personal satisfaction and possibly even material success resulting from her pursuits remains quite high.

Now of course social class will mean different things in different contexts and the level of well-being one experiences will vary greatly depending on a variety 
of things, including the availability and/or quality of education, communal life, housing, nourishment, medical care, etc. at one's disposal. (By well-being I mean an individual's capacity to engage in intrinsically worthwhile activities, where these are not entirely determined by individual preferences. ${ }^{7}$ Yet in industrialized societies, which are where discussions of giftedness routinely take place, middleclass parents are far more likely to have comparable educational attainment, to share similar educational aspirations for their children, and to have the means for procuring them. For socially privileged persons these conditions are highly conducive to interaction with others similarly educated and well-informed. Research shows that peer effects on learning can be as significant as the quality of instruction a child receives (Swift, 2003). Children who socialize with others whose interests have been shaped and molded by well-educated parents are far more likely to adopt similar interests and to cultivate the skills necessary both for meaningful learning and material success.

Why is this important? Its importance lies in the positional outcomes various educational opportunities bestow. Most poor parents also have high aspirations for their children but they are far more likely to have leveled aspirations owing to (a) their lower social-class standing that has undoubtedly resulted in part from access to inferior education; (b) the lack of material means that denies advantages more affluent parents take for granted; and (c) their encounters with discriminatory behavior in the school, marketplace and society generally. Thus, socially privileged parents may avail themselves of structured daycare services, pre-schooling and extracurricular activities that are largely unavailable to those without comparable networking skills or disposable income. Research also shows that the amount and quality of adult-child interaction is hugely different, on average, between social classes (Lareau, 2002; Ogbu, 2003; Rothstein, 2004). Opportunities to learn both inside and outside of the home only further that advantage. In short, in the absence of egalitarian intervention, the positional goods that increase the social capital (e.g. knowledge attainment, job readiness and satisfaction) for one group of children will unavoidably diminish the social capital of less advantaged children. ${ }^{8}$

Given the endless number of opportunities to cultivate abilities and talents that more privileged children typically enjoy, many educational philosophers and policy makers have argued that more ought to be done to challenge all children irrespective of who they are, whether through compensatory means such as Head Start, or simply with higher expectations, role modeling and nurture. Even so, the question of what schools ought to do for the gifted looms large. For all of the advantages that children of socially privileged parents enjoy - including greater access to gifted education programs, magnet and private schools - the fact remains that some children possess exceptional abilities regardless of the income bracket into which they were born. 


\section{Merry: Educational justice and the gifted}

None of this settles the question of what the gifted need or deserve. The definitional quandary does not remove the need to address the learning needs of gifted children. If unchallenged in school, the gifted may simply disengage (as similarly happens with slower learners whose contributions are seldom valued) or languish from boredom, thus affecting their motivation to learn and their general academic performance. In what follows I will argue that a rather strong case can be made for channeling extra resources into the education of the gifted - thus increasing their learning opportunities - on the understanding that doing so is likely to benefit others.

\section{A HYPOTHETICAL ARGUMENT FOR EXTRA PROVISION}

In a society eager to recruit the best and brightest engineers, doctors, researchers, architects and solicitors, ${ }^{9}$ the case for funding and providing a more rigorous curriculum for the most able seems especially strong. Indeed, to many it will seem obvious that societies work against their own best interests when, say, advances in science and medicine stall due to the unwillingness of government to invest in the talents of the gifted. Because we do not wish to needlessly squander the talents of the best and brightest, failing to cultivate the raw material of talent or intelligence such children embody constitutes a form of neglect. (I will return to this.) Once we accept that investing in the best talents is not only fair and good for those individuals but also likely accrues benefits (what economists refer to as 'externalities') to significant numbers of others besides, it remains for us only to identify who the gifted are and determine what specifically can be done to maximize the benefits. Where schools are concerned, learning opportunities need only be provided and arranged so as to foster outcomes that are good for the gifted and optimal for society. Consequently, 'adequate challenge' for some learners may require additional educational resources.

But this is too quick. First of all, prima facie these arguments are consequentialist, and consequentialism will swiftly run into conflict with the requirements of educational justice. Educational justice requires that the State provide basic educational opportunities to all children irrespective of socialclass background or ability, knowing that opportunities are normally contingent on the enabling effects education typically affords. One may call these instrumental benefits because education supplies individuals with the means to meet the various minimal demands that citizenship requires (including basic literacy and financial savvy) and also to enhance one's sense of wellbeing. Thus, with a sufficient amount and quality of education one may take up meaningful vocational pursuits and forms of leisure as well as the relationships that derive from these. More broadly, education also supplies intrinsic 
benefits, which roughly translate as that which enhances human flourishing. Concerning what is just, Amy Gutmann observes that:

\begin{abstract}
A good case can be made for the use of education above the minimum to compensate less gifted and less motivated children for their undeserved disadvantages. Another good case can be made for using educational resources above the threshold to develop new skills and interests in all children, which might be useful to society as well as satisfying to citizens in the future. (Gutmann, I999:I35)
\end{abstract}

Especially given that children with disabilities already struggle to keep up with their more able peers, learning opportunities that appear to favor the already advantaged require further justification. Some children will require more resources for the supplementary services necessary for even the possibility of attaining a normal life, and arguably this should take priority.

Concerning how best to educate the gifted, I have hinted at a number of problems with a special provisions approach, not the least of which is that it promotes the sort of elitism and special treatment with which gifted programming (often in the form of 'flexible' or homogeneous grouping) has rightly or wrongly come to be identified. Further, given the way in which schools have often tended to reproduce social classes and respond to the demands of more privileged and educated parents, a special provisions approach, uncritically applied, will likely favor those whose abilities suggest social privilege rather than exceptional ability. ${ }^{\mathrm{IO}}$ Lastly, the manner in which separate instruction occurs tends to advance the interests of a few at the expense of those who are arguably just as capable of benefiting from more challenging instruction, including many underperforming gifted children.

These responses can be answered, up to a point. First, I have little doubt that unreserved approval could be won for the allocation of extra resources to the education of the gifted if it could be shown that the additional resources would make 'an appropriate contribution to the good of others by training and educating their native endowments and putting them to work [within] a fair system of social cooperation' (Rawls, 200I: 68). In principle, policy makers could design incentives that encourage individuals with greater endowments or motivation to seize enhanced learning opportunities in such a way as to greatly benefit others, especially those less well off. ${ }^{\text {II }}$ Consider the way in which Rawls' second axiom of justice speaks to this:

Social and economic inequalities are to satisfy two conditions: first, they are to be attached to offices and positions open to all under conditions of fair equality of opportunity; and second, they are to be to the greatest benefit of the least-advantaged members of society. (Rawls, 2001: 42-3)

(The first part of this axism,) Fair Equality of Opportunity (FEO) and (the second part of this axism,) Difference Principle (DP) should not be run together. ${ }^{12}$ Yet, allocations of additional resources to gifted students might in 
principle satisfy both parts of this axiom. FEO is satisfied because individuals with similar levels of talent and motivation are to be given the opportunities necessary to exploit their talents in competitions that determine who gets the best social positions. The DP is also satisfied, for it tolerates inequalities so long as over time the benefits to the least advantaged are as great as possible. The DP expresses the idea of reciprocity, and its intent is to regulate the tension between efficiency and (in)equality among free and equal citizens, so that 'those who gain more are to do so on terms acceptable to those who gain less, and in particular to those who gain the least' (Rawls, 200I: I23). Indeed, reasonable investments in the talents and abilities of some allow for what Rawls calls 'mutually beneficial complementarities,' which may - and, with the reciprocity constraint, ought to - enhance the quality of life of others possessing fewer talents. For example, persons with certain talents in medicine may contribute both to the field of medicine generally (comprising many specialties) as well as to the broader society in need of medical services. And it is not an injustice to permit some to excel in certain pursuits while leaving excellence in different pursuits to others. It is only an injustice when opportunities and their rewards are provided for some at the expense of others. Rawls further explains how reciprocity frames the moral responsibility of the more fortunate:

$[\mathrm{T}]$ he better endowed (who have a more fortunate place in the distribution of native endowments they do not morally deserve) are encouraged to acquire still further benefits - they are already benefited by their fortunate place in that distribution - on condition that they train their native endowments and use them in ways that contribute to the good of the less endowed (whose less fortunate place in the distribution they also do not morally deserve). Reciprocity is a moral idea situated between impartiality, which is altruistic, on the one side and mutual advantage on the other. (Rawls, 200I: 76-7)

So the DP supplies a reciprocal basis for aiding the highly abled, and its primary justification is to secure justice for those less abled. Put another way, higher compensation earned by the better endowed would be predicated on developing and using the talents in labor that will benefit the worst off. Indeed, higher compensation becomes the incentive to develop and use the talents of the more able in a specific way, and how the economy is shaped (e.g. through labor and taxation law) ought to ensure that higher compensation for the more talented benefits the worst off. (This is the thinking behind state incentives designed to pay the most experienced teachers higher salaries if they will agree to teach for an extended period in its most underperforming schools.) Reciprocity, on Rawls' theory, is the basis for our responsibility to others in a system built on fair terms of cooperation. Others deserve consideration not on the basis of whether or not they possess certain abilities but rather because they share in common the moral qualities of being human. These qualities include physical and psychological integrity and a capacity for 
sympathy and mutual respect. A number of problems attend the DP vis-a-vis the disabled, which I shall not discuss here. ${ }^{13}$

While FEO and the DP thus appear to be a promising foundation for special educational provision for the gifted, insuperable difficulties remain. First, opportunities - such as special educational opportunities for the gifted generally can not be justified on the basis of morally irrelevant factors, such as native endowments, i.e. those one does not morally deserve. So the gifted do not deserve special educational accommodations in the moral sense of being entitled to or having earned special treatment by virtue of their native endowments. Further, opportunities for the more able and talented are bound by the moral constraints of reciprocity, and failures of reciprocity in existing societies would undermine the apparent Rawlsian basis for special educational provision for the gifted. In existing societies, it is unclear how gifted education and rewards for the more talented would reliably lead to benefits for the less advantaged. So while FEO and the DP go some distance in correcting the defects of formal equality of opportunity - careers open to talents - and do not prohibit properly structured differential provision, FEO nevertheless not only fails to supply us with the justification required for additional resources (if and when they are needed) in order to adequately challenge gifted children, it also fails in my view to support an argument for gifted education. DP may permit the investment of additional resources in the education of gifted students in some circumstances, but does not require it. In the circumstances of justice in which it would be permitted, the consequentialist considerations noted above might recommend it, but in the unjust circumstances of existing societies those consequentialist considerations would not be sufficient to overcome the prima facie injustice of favoring those already favored in the lottery of talents.

\section{WHAT ARE THE GIFTED OWED?}

The question before us invites both empirical and philosophical responses. Empirically, owing to a number of contingencies that will need to be worked out in specific school districts, there is no definitive answer to this question, though I will later discuss a number of specific strategies which teachers and school districts may employ.Yet, philosophically, ethically, it does seem to me that we can say the following: the gifted are owed what all children are owed, namely, a quality education that adequately challenges them. Defining both adequate and challenge is itself difficult, but we can say this: to be adequately challenged is to be presented with tasks that demand substantial growth in ability, understanding and the ability to flourish, together with the resources and encouragement necessary to succeed in those tasks. Remember that flourishing entails the capacity to freely act upon one's choices and live them from the inside. Adequate educational 


\section{Merry: Educational justice and the gifted}

challenges ought to stimulate a broader range of personal interests (not to the exclusion of communal interests); these supply persons with the sorts of intrinsic benefits that enable critically informed choices and the capacity to identify with a way of life from the inside. Flourishing in this sense is closely related to at least a weak form of autonomy: those who are adequately challenged are more likely to explore and reflect upon the merits of various options and pursuits, and are in that sense autonomous and more likely to lead flourishing lives.

Less abstractly, an education that fails to challenge has implications for motivation and learning. Gifted children who lack motivation or interest in school because they are only given educational opportunities challenging enough for 'average' learners are less likely to flourish because flourishing is linked to the eagerness to learn. Hence, educational attainment or success in school is directly tied to the level of motivation children experience vis-a-vis the sorts of educational tasks and projects they are given.

Now, of course, it may be that some children are so constituted that the knowledge, understanding, skills and virtues that educators aim to impart come rather easily to them, and, even in the absence of a challenging education, flourish all the same. Neither flourishing nor autonomy is necessarily undermined in the absence of challenge. Yet the ease with which some learners master new challenges misses the point. Merely because some individuals possess the knowledge and skills they need, or manage to do rather well in life despite being seldom challenged in school is no reason to abdicate the responsibility to challenge all students. Gifted children, like all children, deserve an education that challenges them. Of course, how to determine what constitutes an adequate challenge and in what ways these challenges are best executed must be decided on a case-by-case basis.

So the gifted are at least as deserving of an education that challenges them as more average learners, or learners with disabilities. An education that fails to challenge the gifted - or worse, which facilitates boredom - is no education at all because the main benefit that schools allegedly provide is learning, and to fail to supply this benefit is to vitiate the justification needed for a school's paternalistic control. Put another way, to be remiss in one's responsibility to supply an education that adequately challenges children is to show neglect both to the individuals themselves and potentially to others. It is a form of neglect to the gifted because, as I have stressed, an education that fails to adequately challenge may undermine one's well-being, i.e. one's ability to flourish, and it is potentially a form of neglect of the well-being of others inasmuch as the absence of cultivated talents and abilities may also be injurious to the wellbeing of others. Investing additional resources so that the gifted may be adequately challenged, then, is no injustice except when doing so constitutes a form of neglect of others. Nevertheless, the difficulties in determining what 
constitutes an 'adequate challenge' will remain unresolved because the means for ascertaining what counts as 'adequate' are inescapably contestable. ${ }^{\mathrm{I} 4}$

\section{Objections}

In much of the foregoing discussion I have been considering whether special educational provision is justified for gifted children where this involves additional expense. Though adequate challenges for the gifted do not, in many instances, require additional expense (a point I return to), I take up the subject of additional expense both because advocates for gifted education assume this to be necessary, and also because some - albeit rare - cases of exceptional children may warrant it. As I see it, there are at least two reasonably strong objections to increasing monetary allocations that aim to enhance learning opportunities for the gifted. These are: (I) the return on the investment may be too low, and (2) a scarcity of resources precludes dispensing additional resources to learners who suffer no manifest social disadvantages.

The first objection says that the investment of additional resources in a gifted student may not yield needed talents or the benefits such talent might lead to. Policy makers (and others) have no way of knowing (a) whether the extra investment will translate into goods or services that benefit the talented individuals in question, or other, less talented, persons, but also (b) whether the gifted would nevertheless achieve the various breakthroughs in human endeavor, even in the absence of special provision. Thus the question arises: if there is not a high probability that education to improve the learning outcomes of the gifted will lead to skills and intelligence that, say, advance new technologies that aid humankind, is the allocation of scarce resources for gifted education defensible? Empirically speaking, it seems reasonable to say that public support for funding gifted programming will likely falter if the allocation of resources shows no obvious benefits. ${ }^{\text {Is }}$

The most basic difficulty with this objection is that I argue children deserve an education that adequately challenges them, and a conception of what children deserve is not undermined by the observation that what they deserve does not always produce the benefits hoped for. Another difficulty with this objection is its unreasonably high expectations. Most gifted children cannot reasonably be expected to contribute great things to society, and tying educational provisions to guaranteed, or even probable, outcomes would be worrying for more than the gifted. Indeed, if outcomes must correspond directly with the resources allocated, then we will have a difficult time justifying not only extra provisions for the disabled, but also a free public education to all. ${ }^{16}$ I trust that additional provision for persons with disabilities needs no further defense here. Yet reasons for a free public education to everyone are also easy 
to locate: the public has an interest in developing the capacity for deliberative and responsible citizenship, as well as expanding opportunities to make informed decisions, including the capacity to select meaningful work and be economically self-reliant. None of these is trivial.Yet with the possible exception of the economic benefits of education - which is demonstrable but in any event is not its principle justification - none of these requires that high school graduates contribute to society in a particular way beyond perhaps minimal civic compliance (e.g. operating within the confines of the law). In a free society, individuals must be allowed to desist from exercising their talents or abilities because, however we may lament the misapplication or neglect of talent and ability, legitimate arrangements in a free society cannot abide compulsion to exercise them.

The second objection, that a scarcity of resources precludes dispensing additional resources to learners who suffer no manifest social disadvantages, derives from real-world limitations and budgetary constraints. In a world with limited resources there is often a triage effect in which the administrators of funds must decide whose needs are more pressing. Across the United States, budget deficits have resulted in reduced funding for many educational programs, including music, art, athletics and 'enrichment' programming. Conversely, funding for children with disabilities has either increased or remained stagnant. Against this background, advocates for gifted education sometimes argue that the gifted qualify as students with special needs and are therefore deserving of an education that sufficiently challenges them. With IDEA legislation in the background, the demand here is for equity in the form of equality of resources with accompanying pleas for flexible (homogeneous) grouping, adaptive pacing, or supported opportunities to develop the interests of the gifted (Tomlinson 2005; VanTassel-Baska 2005b). Yet the parallels of children with disabilities to gifted children is fraught with difficulties.

As previously mentioned, IDEA provided children with physical or cognitive disabilities access to a free education for the first time in American history. The legislation places the burden on the State to fund and provide educational services where previously the burden had fallen almost entirely on parents and their limited resources. Educational services for children with disabilities was a significant advance over what was previously an almost complete absence of educational provision for these children - a flagrant example of discrimination. Yet the justification for educational services for children with disabilities surpasses basic Fourteenth Amendment rights and protections. Some children, owing to the cognitive or physical challenges they face, require infinitely more resources in order to even approach the same opportunities others enjoy. A child who is hard of hearing, for instance, depending on the severity of her condition, will require additional staff, supplemental services such as speech therapy, FM systems, and 
curricular accommodations simply in order for her to glimpse a range of opportunities that come easily to those without hearing loss. So the conflation of the educational needs of the gifted with those of students with disabilities is morally objectionable.

Two additional factors must be examined. First, resources for those with disabilities can not be limitless. Reasons may be provided for capping allowable expenses that a school district is able to spend given the other exigencies with which it must contend. In other words, a school district will not be justified in allocating resources for children with disabilities that are unduly disproportionate to what is spent on other students. By 'unduly disproportionate' I mean such as would compromise the quality of learning of 'average' learners or those who are gifted. Further, for some children with disabilities, enhancing their learning opportunities and thus their quality of life still may be insufficient to surmount the limitations the disability imposes. The severity of the disability may simply disallow significant quality of life improvement. Spending decisions will need to be made on a case-by-case basis using an agreed set of criteria.

Second, it is certainly true to say that the gifted face obstacles that lessen their chances of receiving an education that fully develops their potential. Yet given the usually diminished range of capabilities children with physical or cognitive disabilities endure, appeals to maximizing educational opportunities for the gifted (or anyone else) will have little weight. This is because resources are limited and because the cost of maximizing specific types of educational goods for some will likely lead to the neglect of other goods and services (Scheffler, 1985; Gutmann, I999). Unless gifted children suffer from manifest social disadvantages (and many do), it is far from obvious that children who already possess extraordinary intellectual gifts deserve additional resources in order to enhance their learning outcomes when justice may require prioritizing those with learning impediments. However, I have argued that prioritizing any group at the expense of others will conflict with the requirements of educational justice. Of course, justice does not require that educational provisions are equal, only that they are equitable. Provided that all children are receiving an education that adequately challenges them, equitable educational provisions must allow for inequalities that result from the exercise of talents by differently abled and motivated persons.

However, given the huge inequities that plague all liberal societies - and some more than others - justice requires that when extra provisions are made to enhance the learning opportunities of highly able persons (and these provisions need not be limited to schools) the justification for doing so must be compelling indeed. I am arguing that the need to adequately challenge all children in the education they receive may be that justification, even as we note that doing so may be expensive. (However, as I shall note in the next section, many of the 


\section{Merry: Educational justice and the gifted}

gifted can be adequately challenged in ways that require no additional expense.) Of course, state policies and services that aim to abolish endemic inequities such as child poverty would go a much greater distance in achieving justice. For many, poverty - and its correlates like poor health - impair even the will to learn let alone the capacities to be educationally developed. Nevertheless, no amount of justice will remove the differences in motivation and talent that distinguish persons from one another.

Ideally, gains that result from providing the exceptionally able with adequate challenge should also redound to others, and perhaps especially those whose environmental conditions have precluded access to similar opportunities, or whose physical or cognitive endowments have been shortchanged in the natural lottery. However, I have shown that many obstacles may foil such favorable outcomes, not the least of which is that gifted persons may abstain from exercising their talents and gifts in ways that benefit others.

\section{PRACTICAL CONCERNS}

When cases come to light which suggest unusually high ability in more than one area, it will need to be determined how best to organize learning opportunities to serve these students. In some instances, a case may need to be made for altogether separate and advanced instruction. This may take the form of college coursework, independent study, private tutoring or home-schooling, even at the State's expense. In many cases schools simply will not have the trained staff or resources to adequately challenge exceptionally abled children. Yet given the difficulties in defining giftedness that I discussed earlier in this article, determining which children qualify in each subject will remain contested territory. I have focused on a fairly broad interpretation of cognitive ability in part because far more difficult cases involve diagnosing unusual affective or intuitive ability. A clear case might be a nine-year-old who demonstrates advanced mathematical ability in trigonometry, for instance. Whatever the case, the difficulties do not disappear once unusual ability is ascertained. It will remain to be seen whether further investment of energies ought to be given to developing other, as yet unrealized, areas of ability, and it will also need to be determined whether the school possesses the resources to adequately challenge such a pupil or whether recommending services beyond what the school can provide is appropriate. It is important to remember that we are likely talking about an extremely small percentage of children who are of school age. Most evidence suggests that the vast majority of children currently enjoying high ability homogeneous grouping or gifted and talented programming in American public schools do not qualify for the simple reason that most of these children are not so much gifted as they are socially privileged (Borland, 2005; Ford and Harris, I999). 
Separate and/or advanced instruction for the few whose extraordinary abilities surpass their peers by many years will not remove the temptation for socially privileged parents to apply pressure to school administrators to allow their child to participate. Many of these will be parents who are already accustomed to having their way with school administrators and believe that their children are more special than 'other people's children'. To avoid the inevitable demands wealthier and more educated parents will make, clear rules will need to be drawn up, multiple diagnostic systems will need to be in place, and State oversight will need to ensure that fair procedures are consistently applied.

In order to optimize the prospect of children interacting with others of varying abilities, preferences, perspectives and the like, a number of researchers have made compelling arguments for well-planned heterogeneous grouping, as well as curricular choice and multi-age classrooms which allow teachers more flexibility in scaffolding learning opportunities less in accordance with grade-level expectations and more closely allied to individual interests. There is no point in denying that some children learn faster than others or possess a knowledge base that exceeds those of their peers. But homogeneous grouping and separate provisions for faster learners is a poor way of addressing differences among students. ${ }^{17}$ The effects for children who are grouped low include all of the problems associated with stigmatization and disadvantage: lower self-image, alienation from learning and from school, and resentment towards classmates who advance in school at their expense (Davies et al., 2003; Ireson and Hallam, 2005; Lucas, 1999). The answer to these challenges is not that quick learners should be punished or 'held back' so that the learning opportunities of slower learners are ensured. Rather, where it is used, classroom grouping must be equitably structured to benefit all learners.

Of course, adequately challenging all learners is easier said than done. In all areas, including education, this requires more than simply removing the formal barriers of discrimination. For starters it will require that school administrators and teachers become better attuned to the learning needs of the students they teach. This may include more culturally relevant curricula and teaching methods, but also more effective and consistent efforts to connect with the students' parents. ${ }^{\mathrm{I}}{ }^{8}$ And it will most certainly require adequately challenging all children irrespective of their socialization, personality, or set of preferences. Adequate challenges may take several forms, including: cluster grouping/ 'enriched learning' in specific subjects; extracurricular programs; alternative scheduling patterns; mentorships; combined classes; self-paced instruction; concept- or problem-based learning; non-graded classrooms; grade skipping or acceleration; grade telescoping (i.e. time compression of junior/senior high school curriculum); and early college entrance (Renzulli, 2005; VanTassel-Baska, 2005b). 


\section{Merry: Educational justice and the gifted}

Some (Purdy, 2007) have argued that accelerated learning opportunities simply make good economic sense, while others (Clark, 2005) suggest that leveling or flexible grouping (combined with multilevel reading selections and opportunities for in-depth research and group projects) better serves all students. However, typically these recommendations are made available only to children deemed to be 'gifted'. Yet, with the possible exception of grade telescoping, grade skipping and early college enrollment, all children can benefit from the differentiated instruction proposals above. That several of these require a departure from the status quo is no reason to sidestep the responsibility to pursue them. Good teachers look for ways to expand opportunities for student self-selection; know how to exploit mentorships; maintain high expectations; use a variety of resources and instructional strategies; and employ continuous and varied assessment tools. Most of these involve no additional expenditure.

\section{O N C L U S I O N}

In this article I have specifically examined two questions. First, in asking what constitutes a gifted person I have cast doubt on whether giftedness as it is presently conceptualized is sufficient justification for maintaining high ability grouping or separate gifted instruction. I have also examined whether children with unusual abilities can be compared with those with disabilities and have found the comparison wanting. Second, I have examined whether gifted children are owed additional educational provisions as a matter of justice. I have shown that the gifted may be adequately challenged in schools without additional expense but that some cases clearly warrant alternative solutions that may incur additional cost. Above all, I have argued that gifted children deserve to be adequately challenged as much as anyone else - so long as those challenges do not compromise the education of other children - because, to a significant degree, their ability to flourish hinges on it.Therefore, whether teachers facilitate adequate educational challenges for all children is a matter of paramount ethical importance. When denied an education that challenges them, all children, including the gifted, suffer neglect.

I have conceded that determining whether a child has been adequately challenged is indeterminate partly because its meaning must be decided upon in different times and places according to the availability of resources, the complexity and specificity of needs, and the political will to address those needs. I have also pointed out that various incentives, methods and programs may be used to adequately challenge students; further, meaningful assessments will need to be developed to indicate with some degree of reliability whether students have demonstrated significant growth. Where reliable diagnostics determine actual cases of exceptionality, staff will need to determine whether that student can realistically be well served in the public school or whether she is better served 
elsewhere. Either way, justice will require that such a student is adequately challenged even as we must concede that what is meant precisely by 'adequately challenged' remains, for the moment, an unsettled matter.

Gifted or not, no child deserves merely the educational minimum; ${ }^{19}$ rather, each child deserves to be educated in ways that stimulate and provoke critical thinking and creativity regardless of parental input, teacher recommendation and test scores. Yet, currently, more needs to be done to distinguish the truly gifted from the socially privileged. Ending grouping practices and programming that favor the children of the socially privileged will require administrative backbone, instructional differentiation, and generally more planning and effort there's no getting around that. Yet, if teachers are attuned to the needs of their students, classroom instruction can be arranged so that learning opportunities are enhanced (though not maximized) for all children and not just a lucky few. And what is education for in the first place, if not to foster the intellectual and developmental growth of all children according to their individual needs?

\section{A C K N OW LE D G E M EN T S}

I am grateful to Eamonn Callan, Randall Curren, Doret de Ruyter, Michael Hand and Charles Howell for their useful feedback, and also to Bill New and Matt Tedesco for comments on an earlier draft.

\section{NOTES}

I. In I990, the Americans with Disabilities Act was passed, moving the protection of persons with disabilities further into the public sphere. Exceptions remained in the private sphere. Thus private schools are not held to the requirements of the legislation. In 1997, the Act was reinstated with a few more provisions.

2. Trends in the United Kingdom appear to be moving in the opposite direction. The British schools minister Lord Adonis announced recently that the brightest 5 per cent of pupils are to have their names entered into a national register. All secondary schools in the United Kingdom will receive letters encouraging teachers to recommend the names of pupils they wish to be entered into a database for gifted and talented so that their progress can be tracked as they move through school. Children are to be selected according to both academic test results as well as abilities in music, drama, dance and sport. Though the stated aim of the British government is to widen access for pupils from poorer backgrounds, the outcry against the initiative by teachers' unions and education theorists suggests that a national register will give middle-class parents even more reason to pressure their children to succeed on high stakes exams, as well as pressure school officials to select their children. See Cassidy (2006).

3. In fact, more than 30 states have legislation providing special programming for gifted learners.

4. Of course, parents of the gifted do not usually object to special services being provided for children of poor families; they merely ask that the schools their 


\section{Merry: Educational justice and the gifted}

children attend provide the kinds of differentiated instruction that will sufficiently challenge them.

5. This is a bold and controversial claim for which there is no conclusive proof. The basis for my claim is threefold: (I) the available (albeit conflicting) studies which suggest that truly exceptional children are quite rare; (2) my experience as a teacher, researcher and a staff member in four separate schools districts of varying size; finally, (3) my professional experience with socially privileged undergraduates, many of whom have undeservedly received the gifted label in high schools. In fact, there are no reliable statistics available suggesting what percentage of the population is exceptionally able. However, a fairly significant percentage of children manage to enjoy the gifted label in American schools. Davidson and Davidson (2004:I8) write: 'As many as one in six American students between the ages of four and eighteen - some Io million young people - receive this label [gifted] for scoring one standard deviation or more above the norm on intelligence tests.' Incidentally, this is consistent with the figures emanating from the United Kingdom, where a recent report from Wales indicated that 27 per cent of school children were assessed as 'having more academic ability'. See Isaac (2006). Even so, of the 62 million school-age children in the United States, only 62 thousand have IQs over I45, a fairly small number. See Cloud (2007).

6. Gardner himself rejects the association of multiple intelligences with claims for gifted education (I999: 89), though this has not prevented gifted advocates from appropriating his theory.

7. T. M. Scanlon (I995: II2-I3) notes that well-being relates to 'an idea of the quality of a life for the person who lives it that is broader than material and social conditions, at least potentially broader than experiential quality, different from worthiness or value, and narrower than choiceworthiness all things considered.' John White (2007) adds that well-being is desire dependent, culturally specific and circumscribed by a loose collection of people. Further, the 'most authoritative voices on what constitutes our well-being are among those with a wide acquaintance with all sorts of goods' (White, 2007: 23).

8. Naturally, parental involvement varies considerably. While stereotypes seldom allow for it, the fact remains that many poor parents invest immeasurably in their child's education while many a wealthy parent is indisposed and uninterested.

9. Each of these vocations implies a significant amount of social prestige. Many others not mentioned here are unquestionably complex roles requiring unusual ability. The skills many short-order cooks and administrative assistants possess seem to me to be illustrative examples.

IO. I am not interested to settle here whether it is justifiable for wealthy parents to ensure certain advantages for their children. Compelling arguments tug in opposite directions concerning what the proper bounds of parental advocacy entail. See the discussions in Swift (2003) and Archard and Macleod (2002). My interest here is merely to point out the manner in which some parents provide advantages for their children that potentially harm other children.

II. This may take a variety of forms, including a progressive tax code carefully designed to benefit the less-advantaged. 


\section{Theory and Research in Education 6(I)}

I2. Rawls' formulation requires both that the Liberty Principle (i.e. the first principle of justice) as well as the principle of equality of opportunity be lexically prior to the DP. The Liberty Principle states that "each person has the same indefeasible claim to a fully adequate scheme of equal liberties, which scheme is compatible with the same scheme of liberties for all' (Rawls, 200I: 42). Lexical priority means that the conditions for the former must first be satisfied before opportunities are to be arranged that benefit the least advantaged. This means that the least advantaged are not to be prioritized if and when liberty is infringed upon, such as when some persons with disabilities argue that medical intervention is an affront to their autonomy. Indeed, many persons with disabilities exercise their basic liberty in refusing corrective measures (e.g. cochlear implants). Therefore, left on its own the DP is hamstrung, for Rawls' second axiom of justice clearly allows for inequalities that result from the exercise of talents owned by differently abled and motivated persons.

I3. For example, Rawls' theory assumes that all persons operating within a system of fair cooperation operate 'within the normal range' of functioning, and the moral powers on which this system is based are described entirely in cognitive terms, thus seeming to exclude those with severe mental impairments. For a recent critique of Rawls on exactly this point, see Nussbaum (2006).

I4. Asking children whether they feel adequately challenged will prove as unreliable as administering tests that some will interpret to mean that high scorers are not being challenged enough.

I5. With little difficulty one could catalogue a long list of tragic Western artists and intellectuals whose talents and abilities did little more than facilitate egoistic and fruitless pursuits while bringing untold suffering onto others whose lives they shared.

I6. Due to the inequitable effects of funding schemes, local control, racist legacies and the vagaries of personal circumstance, equality of opportunity remains an unrealized ideal, but its promise nonetheless is embedded in the justification for its provision in the first place.

I7. Most studies - inside and outside the United States - suggest that homogeneous ability grouping benefits high end learners. See Desbottes and Nicholls (n.d.); Gamoran (1986, 1992); Ireson and Hallam (2005). Other studies produce conflicting results. Whatever the level of perceived ability, many believe that the pace of instruction, matched to students of like perceived ability, may provide opportunities to accelerate or reinforce the necessary skills students need to acquire. Nevertheless, critics contend that grouping greatly disadvantages students lacking in the skills other children bring to school by virtue of their social class background.

I8. Clearly smaller districts with a low mobility rate will have an easier time with this.

I9. Nevertheless, the current emphasis on 'proficiency' in the US under the No Child Left Behind Act (2002) accords well with the Supreme Court sentiment that the State is not required to provide an ideal education but merely a basic education. Hence, the allocation of resources to move students beyond proficiency is simply not on the table. 
Archard, D. and Macleod, C., eds (2002) The Moral and Political Status of Children. Oxford: Oxford University Press.

Borland, J. H. (2005) 'Gifted education without gifted children: The case for no conception of giftedness', in R. Sternberg and J. Davidson (eds), Conceptions of Giftedness, pp. I-I9. New York: Cambridge University Press.

Borland, J. H. and Wright, L. (I994) 'Identifying and educating poor and underrepresented gifted students', in K. A. Heller, F. J. Monks, R. J. Sternberg and R. F. Subotnik (eds), International Handbook of Research and Development of Giftedness and Talent, pp. I64-I7I. London: Pergamon Press.

Callahan, C. M. and Miller, E. M. (2005) 'A child-responsive model of giftedness', in R. Sternberg and J. Davidson (eds), Conceptions of Giftedness, pp. 38-5I. New York: Cambridge University Press.

Cassidy, S. (2006) 'Do bright children need to be taught separately, and is it good for them?', The Independent (I2 July): $3 \mathrm{I}$.

Clark, L. (2005) 'Gifted and growing'. Educational Leadership 63(3): 56-60.

Cloud, J. (2007) Failing our geniuses. Time (27 August): 4I-6.

Davidson, J. and Davidson, B. (2004) Genius Denied: How to Stop Wasting our Brightest Young Minds. New York: Simon \& Schuster.

Davies, J., Hallan, S. and Ireson, J. (2003) 'Ability groupings in the primary school: Issues arising from practice', Research Papers in Education I8(I): 45-60.

Desbottes, A. and Nicholls, T. (n.d.) 'What is the impact of cross-phase, crosscurricular learning on gifted and talented pupils?', Education Review I8(I): 79-84.

Ford, D.Y. and Harris, J. J. (I999) Multicultural Gifted Education. New York:Teachers College Press.

Gamoran, A. (1986) 'Instructional and institutional effects of ability grouping', Sociology of Education 59: I85-98.

Gamoran, A. (1992) 'Is ability grouping equitable?', Education Leadership 58(7):II-I7.

Gardner, H. (1999) Intelligence Reframed. New York: Basic Books.

Gordon, E. W. and Bridglall, B. L. (2005) 'Nurturing talent in gifted students of color', in R. Sternberg and J. Davidson (eds), Conceptions of Giftedness., pp. I2O-I46. New York: Cambridge University Press.

Gutmann, A. (I999) Democratic Education, 2nd edn. Princeton: Princeton University Press.

Harry, B. and Klingner J. (2006) Why Are There so many Minority Students in Special Education? Understanding Race and Disability. New York: Teachers College Press.

Heller, K. A., Perleth, C. and Lim, T.K. (2005) 'The Munich model of giftedness designed to identify and promote gifted students', in R. Sternberg and J. Davidson (eds), Conceptions of Giftedness, pp. I47-I70. New York: Cambridge University Press.

Ireson, J. and Hallam, S. (2005) 'Pupils' liking for school: Ability grouping, selfconcept and perceptions of teaching', British Journal of Educational Psychology 75: 297-3II.

Isaac, J. (2006) 'A talent for doing best for the gifted', The Times Educational Supplement Cymru (7 July): 5 .

Lareau, A. (2002) 'Invisible inequality: social class and childrearing in black families and white families', American Sociological Review 67(5): 747-76. 


\section{Theory and Research in Education 6(I)}

Losen, D. J. and Orfield, G. (2002) Racial Inequity in Special Education. Cambridge, MA: Harvard Education Press.

Lucas, S. (1999) Tracking Inequality: Stratification and Mobility in American High Schools. New York: Teachers College Press.

Moore, J., Ford, D. and Milner, H. R. (2005) 'Underachievement among gifted students of color: implications for educators', Theory into Practice 44(2): I67-77.

Nussbaum, M. (2006) Frontiers of Justice: Disability, Nationality, Species Membership. Cambridge, MA: Harvard University Press.

Ogbu, J. (2003) Black American Students in an Affluent Suburb: A Study of Academic Disengagement. Mahwah, NJ: Lawrence Erlbaum Associates.

Purdy, L, (2007) 'Educating gifted children', in R. Curren (ed.), Philosophy of Education: An Anthology, pp. 3I4-I9. Oxford: Blackwell.

Rawls, J. (200I) Justice as Fairness: A Restatement. Cambridge, MA: Harvard University Press.

Renzulli, J (2005) 'Applying gifted education pedagogy to total talent development for all students', Theory into Practice 44(2): 80-9.

Rothstein, R. (2004) Class and Schools: Using Social, Economic, and Educational Reform to Close the Black-White Achievement Gap. New York: Teachers College Press.

Scanlon, T. M. (I995) What We Owe Each Other. Cambridge, MA: Harvard University Press.

Scheffler, I. (1985) Of Human Potential: An Essay in the Philosophy of Education. Boston: Routledge and Kegan Paul.

Swift, A. (2003) How not to be a Hypocrite: School Choice for the Morally-Perplexed Parent. London: Routledge.

Tomlinson, C. A. (2005) 'Quality curriculum and instruction for highly able students', Theory into Practice 44(2): I60-6.

VanTassel-Baska, J. (2005a) 'Domain-specific giftedness', in R. Sternberg and J. Davidson (eds), Conceptions of Giftedness, pp. 358-376. New York: Cambridge University Press.

VanTassel-Baska, J. (2005b) 'Gifted programs and services: What are the nonnegotiables?', Theory into Practice 44(2): 90-97.

White, J. (2007) 'Well-being and education: issues of culture and authority', Journal of Philosophy of Education 4I(I): I7-28.

Winstanley, C. (2003) Too Clever by Half: A Fair Deal for Gifted Children. Stoke on Trent:Trentham Books.

\section{BIOGRAPHICAL NOTE}

MICHAEL S. MERRY is visiting professor in educational studies at Beloit College and is the author of many articles in the philosophy of education. He is also the author of Culture, Identity and Islamic Schooling: a philosophical approach. [email: merrym@beloit.edu] 